\begin{tabular}{|ll}
$\begin{array}{l}\text { DEMOCRATIC } \\
\text { REPUBLIC } \\
\text { OF CONGO }\end{array}$ & $\begin{array}{l}\text { Congo volcano } \\
\text { Early warning failed } \\
\text { to avert tragedy of } \\
\text { Goma eruption }\end{array}$ \\
$\begin{array}{l}\text { Nyiragongo } \\
\text { Goma }\end{array}$ & $\begin{array}{l}\text { Lost property } \\
\text { Experts call for } \\
\text { reform of Japan's } \\
\text { patent system } \\
\text { p354 }\end{array}$
\end{tabular}

\title{
Panels' conflicting views cloud legal future of human cloning
}

Erika Check, Washington

With the US federal government deadlocked on legislation to ban or restrict the cloning of human embryos, several state governments are moving to pass their own laws on the issue.

If it continues, the flow of state legislation could result in a patchwork of rules across the United States, with 'therapeutic' cloning permitted in the more liberal coastal states, but banned in the conservative heartland.

The stalemate on the issue in Washington was neatly captured on 18 January, when two important protagonists in the debate presented strongly conflicting visions of appropriate rules for cloning.

On that day, a National Academy of Sciences panel, chaired by developmental biologist Irv Weissman of Stanford University, released the findings of an eight-month study. The panel recommended a legislative ban on reproductive cloning but urged the government to allow research on cloned human embryos.

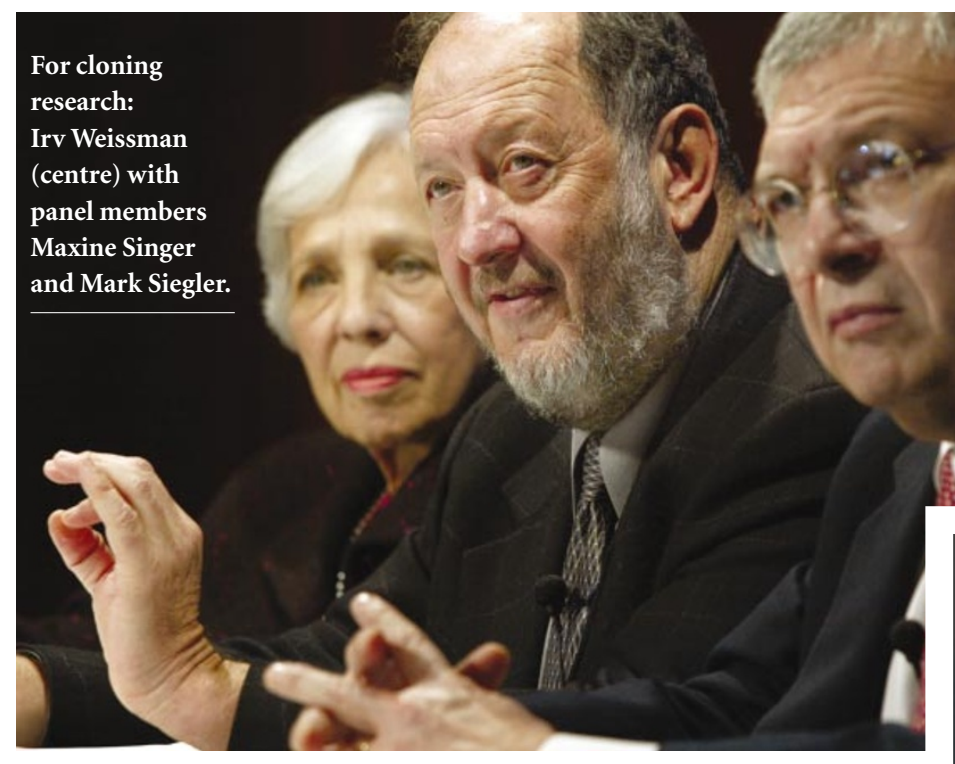

Meanwhile, a few blocks away in the Loews L'Enfant Plaza Hotel, the President's Council on Bioethics held its first meeting and heard several of its members energeti-

\section{Geneticist takes top job at museum}

Sally Goodman, Paris

Members of staff at the National Museum of Natural History in Paris are hoping that the appointment of a new president on 14 January will put an end to years of internal crisis there.

Bernard Chevassus-au-Louis, a specialist in the genetic improvement of farmed fish, comes from the French food safety agency, AFSSA, where he was president.

The museum has been managed by an interim administrator since September 1999, while a committee of external scientific advisers drew up plans to reform its research activities (see Nature 409, 273; 2001).

Chevassus-au-Louis is expected to reorganize the museum's 30 laboratories into a smaller number of departments around a theme of diversity in the living world. "The museum needs a coherent global vision,” he says.

The new president will be supported by a director responsible for the day-to-day running of the museum, and by a new scientific advisory committee. He will also appoint a director of collections to oversee a major planned renovation of specimen housing and cataloguing at the museum.

"The re-emphasis on the care of collections is good news for the world scientific community," says Peter Raven, director of the Missouri Botanical Garden in St Louis.

The government has promised 150 million euros (US\$133 million) over six years - less than the $\mathbf{4 0 0}$ million euros thought necessary for the renovation, but Chevassus-au-Louis believes the rest will follow. cally denounce the use of cloning for research purposes. Indeed, the council's chair, Leon Kass, a bioethicist from the University of Chicago, declined to use the term 'therapeutic cloning', after council members objected to it.

"I do not believe there is a distinction between reproductive and therapeutic cloning. I think the distinction itself is morally problematic," said council member Robert George, director of the James Madison Program in American Ideals and Institutions at Princeton University.

The president's 18-member council consists of 15 academics - including 3 scientists - ajournalist and 2 clinicians. The scientists urged the others to consider the potential therapeutic benefits of research cloning. "The question of how important this research may be to medicine is totally unresolved, which is a reason why we must be cautious about not preventing American scientists from pursuing these questions," said Janet Rowley, a biologist at the University of Chicago.

Kass himself noted that in the past he has 
argued that the only way to enforce a ban on reproductive cloning would be to ban research cloning as well. He warned, however, that this did not necessarily mean that the panel would oppose the practice. "There is a division in this room about the feasibility and morality of doing research cloning, and where people will come out on that I don't know," he said.

Some observers emphasized the Bush council's strong conservative leanings. "This panel is heavily theological and religious and is also made up of many people whose first impulse about science and technology is sceptical," said Arthur Caplan, director of the Center for Bioethics at the University of Pennsylvania.

In any case, it remains unclear what role the panel will have in influencing federal cloning legislation. The House of Representatives has already supported a law that would ban cloning altogether, whereas the Senate is likely to favour a narrower ban that would allow therapeutic cloning.

With neither body inclined to budge, observers say that Bush may have little to gain from taking a strong position on the issue, whatever his bioethics council recommends. Bush has already expressed a desire to see all types of cloning outlawed, and his council may well adopt the same position. But this does not necessarily mean that he will take the politically risky path of trying to force the Senate's hand.

As the federal government considers its position on the issue, science marches on. In November, the Massachusetts biotechnology firm Advanced Cell Technology claimed that it had cloned human embryos, prompting many states to draft their own cloning laws.

Last week, for example, an advisory council weighed in on California's ban on reproductive cloning, which is set to expire at the end of this year. The advisory council, chaired by Hank Greely, a bioethicist at Stanford University, recommended that California renew the ban, but also said that the state should continue to allow therapeutic cloning. The state legislature will soon be considering whether to make all cloning illegal or simply to outlaw reproductive cloning and leave research cloning untouched.

Across the country in Wisconsin, the state in which James Thomson first isolated human embryonic stem cells, legislators are evaluating several proposals to restrict cloning. State houses in Massachusetts, Kentucky and Colorado are also debating their own laws.

But a Florida proposal is perhaps the most prophetic. The bill bans cloning for any purpose, and adds a uniquely American twist by allowing a cloned human to sue the scientists involved in his or her creation.

\section{Craig Venter leaves top Celera post \\ Colin Macilwain, Washington \\ Craig Venter, founder of Celera, is stepping \\ down as president of the Rockville, Maryland- \\ based biotechnology company, which last year published a version of the human genome sequence (Science 291, 1304-1351; 2001). \\ Tony White, chairman and chief \\ executive of Celera's parent corporation, \\ Applera, will stand in as president for Celera while a new president is sought, according to a statement issued by Applera on 22 January. \\ Venter, who was travelling and \\ unavailable for comment, will remain chair of Celera's scientific advisory board. But the statement said he will spend more time on his duties as chair of The Institute for Genomic Research, the Rockville company operated by his wife, Claire Fraser. \\ Although Venter was widely credited with Celera's success in genome sequencing, doubts have been expressed about the company's long-term business model, which has switched emphasis from users paying for data access to drug development.}

\section{Japanese labs could merge in drive for sharper focus}

\section{David Cyranoski, Tokyo}

Moves are afoot to merge several of Japan's leading government laboratories into a single structure somewhat similar to Germany's Max Planck Society.

Advocates of the merger say that it would provide a focal point for top-quality research, and would aid collaboration between laboratories specializing in different disciplines. But critics are already preparing to resist the plan, which will surface later this month in a discussion paper to be published by the education ministry.

The plan would bring together some 14 government-run research institutes, including the High Energy Accelerator Research Organization (KEK) in Tsukuba, north of Tokyo, the National Institute of Genetics in Mishima, south of the capital, and the National Museum of Ethnology in Osaka.

Proponents of the reform in the education ministry are hoping to build a structure that could allow quick entry into new fields of research, close down outdated research facilities, rationalize administration and incorporate a more systematic approach to intellectual property (see page 354 ). They say that the new structure would give the laboratories a stronger footing to survive the Japanese government's continuing efforts to streamline all of its activities.

But the proposal is getting mixed reviews. Yoshiki Hotta, director of the National Institute of Genetics, points out that the merged group would still not be strong enough to be a central core for Japanese scientific research unless other major research institutes, such as the Institute of Physical and Chemical Research (RIKEN), were included. "If it could give scientists more of a voice in the government, it would be good," says Hotta, "but it's not clear that that will happen."

Other institute heads say they fear that the merger would force them into negotiat- ing their research programmes with other, unrelated institutes, instead of directly with the education ministry, as happens at present. "These institutes have such different purposes,” observes KEK's director, Hirotaka Sugawara. "How can they have a consistent organization that functions as one?"

But Hideo Mohri, president of Okazaki National Research Institutes (ONRI) in Aichi, another institute included in the plan, is enthusiastic. When the ONRI was formed from three institutes, they each retained autonomy, he says. "A merger is not a bad direction to go in," Mohri says.

Most agree that a merger could create opportunities to share resources. KEK's X-ray facility could prove useful, for example, to archaeologists at the National Museum of Japanese History who want to identify artefacts, says Sugawara.

"It could work, but many things still need to be ironed out," says Hotta. Details about how to split the financial resources between institutes with budgets of widely varying sizes are still under discussion.

If it is approved by the education ministry and the Council for Science and Technology Policy, the reform plan could be implemented by 2004 , government officials say.

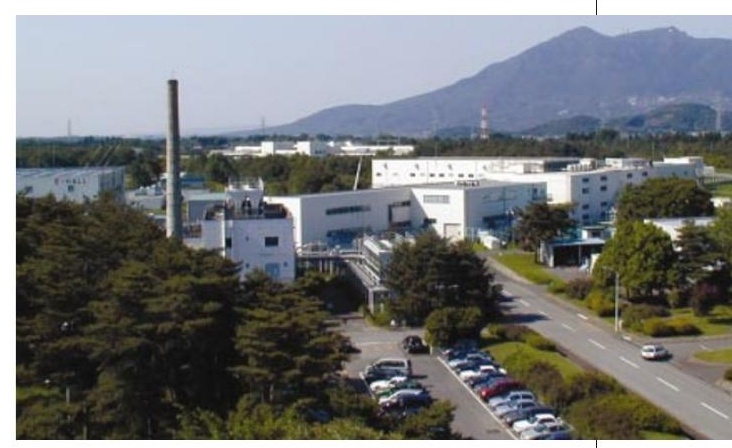

The High Energy Accelerator Research Organization (KEK) may merge with other labs. 